структурных элементов паренхимы и стромы, имеющих признаки функциональной незрелости, характеризующую морфологическую картину гипотиреоза уже после рождения (крысы 1-7-х суток постнатального онтогенеза).

Ключевые слова: щитовидная железа, стафилококковый анатоксин, крысы.

\title{
STRUCTURAL AND FUNCTIONAL CHANGES OF THYROID GLAND OF RATS IN EARLY DAIRY PERIOD AFTER PRENATAL ANTIGEN LOAD
}

\section{O.V. Fedosieieva}

Abstract. We obtained results on reactive changes in the functional state of the thyroid gland after prenatal staphylococcal toxoid antigen action are fairly new. As a result of insidefetal input of staphylococcal toxoid more pronounced elements of structure in parenchyma and stroma were formed, but they showed signs of functional immaturity, leading to the presence of morphological picture of hypothyroidism after birth (postnatal day 1-7 rat ontogeny).

Key words: thyroid gland, staphylococcal toxoid, rats.

State Medical University (Zaporizhzhia)

Рецензент - доц. А.А. Ходоровська

Buk. Med. Herald. - 2015. - Vol. 19, № 3 (75). - P. 197-199

Надійшла до редакції 09.04.2015 року

(С) О.В. Федосєєва, 2015

УДК 616.36-002.2-004-073.432.19

Ю.Я. Федуленкова

\section{ПАТОМОРФОЛОГІЧНА ВЕРИФІКАЦІЯ УЛЬТРАСОНОГРАФІЧНОЇ ТА КОМП'ЮТЕРНО -ТОМОГРАФІЧНОЇ ДІАГНОСТИКИ ХРОНІЧНОЇ ДИФУЗНОЇ ПАТОЛОГІЇ ПЕЧІНКИ}

Харківський національний медичний університет

Резюме. За результатами патоморфологічного дослідження 105 випадків (63 - жирового гепатозу (ЖГ), 12 - хронічного гепатиту (ХГ), 28 - цирозу печінки (ЦП), два - без патології печінки) оцінено діагностичну цінність ультразвукового (УЗД) й комп’ютернотомографічного (КТ) методів діагностики хронічної дифузної патології печінки (ХДЗП). Показано, що діагностична цінність УЗД та КТ є зіставлюваною. Узагаль-

Вступ. В останні роки зростає інтерес до проблеми хронічних дифузних захворювань печінки (ХДЗП), їх діагностики взагалі і неінвазивної - зокрема $[2,7]$. Референтним щодо діагностики ХДЗП досі залишається патоморфологічний метод $[4,9]$. Він безперервно удосконалюється [8, 12], проте його якість залежить від адекватності забору матеріалу, і тут у нагоді стають променеві методи [2]. Не відкидаючи провідної нині ролі прижиттєвої біопсії в діагностиці ХДЗП, не припиняється пошук гідної їй альтернативи $[3,11]$, i найбільш загальновизнаний та перспективний напрямок - удосконалення засобів променевої діагностики. Більше того, дослідники воліють досягти таких високих стандартів променевої діагностики ХДЗП, що це дасть змогу зовсім відмовитися від біопсії [1]. Проте нині в кращому випадку за ХДЗП вдається зводити необхідність біопсії до мінімуму завдяки прогресивним технологіям візуалізації та лабораторної діагностики.

Найрозповсюдженішими $\mathrm{i}$ доступними в практичній охороні здоров'я методами діагности-

(с) Ю.Я. Федуленкова, 2015 нена специфічність обох методів становила 50 (40; $71,4) \%$, позитивна передбачувальна цінність $75,0(50,0 ; 86,4) \%$. Інформативність УзД вища за рахунок оцінки як морфологічних, так і функціональних показників.

Ключові слова: жировий гепатоз, хронічний гепатит, цироз печінки, ультрасонографія, комп'ютерна томографія, патоморфологія.

ки ХДЗП є ультразвукове дослідження (УЗД) та комп'ютерна томографія (КТ) [2, 7]. Все більшого значення набувають також еластографія та магнітно-резонансна томографія. Пошук діагностично цінних й інформативних параметрів ультразвукової та КТ-семіотики $є$ актуальним.

Мета дослідження. Визначити діагностичну цінність КТ та УЗД шляхом зіставлення з даними патоморфологічного дослідження.

Матеріал і методи. Досліджено 105 випадків (103 - ХДЗП, два - контроль 3 інтактною печінкою) на базі патанатомічного відділення КЗОЗ «Обласна клінічна лікарня - Центр екстреної медичної допомоги і медицини катастроф» (м. Харків) протягом 2012-2013 рр. Оцінено відповідність даних УЗД (105 випадків), КТ (33 випадки) результатам аутопсії печінки (105 випадків).

За стандартними методиками проводилися: прижиттєві УЗД та КТ, УЗД-контрольована черезшкірна пункційна біопсія печінки, після смерті автопсія. Ультразвукові дослідження здійснено на обладнанні Xario SSA 660A (Toshiba Medical Syste- 
ms, Японія); КТ-дослідження - на мультиспіральному томографi Aquilion 16 (Toshiba Medical Systems, Японія) на базі «МДЦ Експерт-Харків»; для болюсного КТ-контрастування застосовували «Омніпак350». Патоморфологічний матеріал оцінювався макро- та мікроскопічно. Гістологічний матеріал проводили за загальноприйнятою гістологічною методикою (Пирс Э., 1962), забарвлювали гематоксиліном і еозином, пікрофуксином за Ван-Гізон, за Маллорі, суданом III, вивчали на світлооптичному мікроскопі «Olympus BX-41». Ступінь жирового гепатозу (ЖГ) оцінювали за кількістю гепатоцитів iз жировими включеннями (Чирський, 2009). За хронічного гепатиту (ХГ) визначали вираженість фіброзу за шкалою METAVIR (1994) і активність процесу за Knodell R. G. (1981).

Логіко-статистичний аналіз результатів через особливості розподілу кількісних ознак здійснено непараметричними методами із використанням Statsoft Statistica 8.0. Обчислювали медіану (Me) та міжквартильний інтервал із наведенням значень нижнього, 25 \% квартиля (LQ) та верхнього, 75 \% квартиля (UQ), результат для стислості виражали у вигляді Me (LQ; UQ). Відмінність кількісних показників оцінювали за допомогою U-критерія Манна-Уітні (Mann-Whitney), якісних - за допомогою кутового перетворення Фішера (величину емпіричного кута позначали літерою $\varphi)$. Розраховували наступні показники діагностичної цінності методів: чутливість (відношення істинно позитивних (ІП) до суми істинно позитивних та помилково негативних (ПН) результатів), специфічність (відношення істинно негативних (IH) до суми істинно негативних та помилково позитивних (ПП) результатів), позитивну передбачувальну цінність (ППЦ, відношення істинно позитивних (IП) до суми істинно позитивних та ПП результатів). Критичний р-рівень - 0,05.

Результати дослідження та їх обговорення. Гістологічне дослідження фрагментів печінки за ХДЗП, діагностованих за допомогою УЗД й КТ, виявило в 63 (60,0 \%) випадках ознаки ЖГ, у частині випадків - із хронічним венозним повнокров'ям; у 12 (11,4 \%) випадках виявлено ХГ; у 28 $(26,7 \%)$ випадках відмічався розповсюджений фіброз і утворення вузликів-регенератів, які заміщують паренхіму, що характерно для цирозу печінки (ЦП); у двох (1,9 \%) випадках не виявлено будь-яких структурних змін печінки, ці випадки склали контрольну групу.

У групі ЖГ вік пацієнтів $64(60 ; 73)$ роки (коливався в межах 20-85 років), гендерна відмінність за віком між чоловіками і жінками відсутня - 63,5 $(57,5 ; 71,5)$ років проти $67(62 ; 74)$ років відповідно, $\mathrm{p}=0,32$; частота ЖГ у чоловіків вища (40 випадків, 63,5\% проти 23 випадків, 36,5\%, $=3,07 ; \mathrm{p}<0,01)$. Причина розвитку ЖГ у 46 (73\%) випадках асоційована 3 патологією серцевосудинної системи і органів дихання; в 11 (17,5\%) випадках - 3 інтоксикацією, 3 них у 6 (54,6\%) алкогольною, а в $5(45,4 \%)$ - пухлинною на тлі хіміотерапії; у 6 (9,5 \%) випадках - 3 ендокринно- метаболічними порушеннями, 3 них у 4 (66,7 \%) випадках із цукровим діабетом, у 2 (33,3 \%) аліментарним ожирінням.

Maca печінки більша за контроль: $1890(1868 ; 1900)$ г проти $1594(1590 ; 1598)$ г відповідно $(\mathrm{p}=0,02)$. У 43 випадках $(68,3 \%)$ на розрізі тканина печінки мала характерний вигляд мускатного горіха (з ділянками червонуватого і жовтуватого кольору), у 20 випадках $(31,7$ \%) жовтуватий, сірувато-жовтуватий або жовтуватоглинистий колір. Гістологічного у випадку «мускатної» печінки - різке розширення і повнокров'я центральних вен і прилеглих міжбалкових капілярів, наявність діапедезних крововиливів. У деяких полях зору - пігмент гемосидерин поєднувався 3 наявністю сидерофагів. За периферією часточок - дрібно- i великокрапельна жирова дистрофія гепатоцитів (безколірні округлоовальні пустоти з чіткими краями, втрата гепатоцитами властивої їм форми і балкоподібного розташування, набуття округлої форми). У шести випадках із 43 відмічалася дискомплексація гепатоцитів, коли втрачався зв'язок у печінковій балці, і їх відособлення з наявністю вакуольної дистрофії, поліморфноклітинної інфільтрації різного ступеня вираженості і загибель окремих груп клітин. Запальні зміни супроводжувалися різного ступеня фіброзуючою реакцією - портальний, перипортальний, перивенулярний і перисинусоїдальний фіброз в одиничних полях зору з формуванням фіброзних септ. У деяких полях зору в цитоплазмі гепатоцитів виявлявся пігмент ліпофусцин золотисто-жовтуватого кольору.

Іншою гістологічна картина була у випадках, коли макроскопічно печінка була в'ялою і мала жовтуватий або сірувато-жовтуватий, або жовтувато-глинистий колір. В 11 випадках 320 $(55,0 \%)$ місцями виявлялося пилоподібне, дрібно-, середньо-, великокрапельне ожиріння гепатоцитів, одиничних чи груп, в окремих спостереженнях - усієї паренхіми печінки. У деяких полях зору - злиття двох-трьох заповнених жиром гепатоцитів, які утворюють жирові кісти. Гепатоцити 3 ознаками жирової дистрофії в частині полів зору локалізувалися переважно довкола портальних трактів, центральних вен, а в частині полів зору - не мали прив'язки до анатомічних структур печінки. У п'яти випадках 320 (25,0 \%) відмічалася жирова дистрофія гепатоцитів 3 лобулярною запальною інфільтрацією. У трьох випадках з 20 (15,0 \%) стеатоз печінки поєднувався 3 лобулярною запальною інфільтрацією, дистрофічними і фокальними некротичними змінами гепатоцитів. В одному випадку з 20 (5,0 \%) відмічалася жирова дистрофія гепатоцитів 3 початковою перебудовою часточкової структури печінки.

Під час аналізу ступеня стеатозу печінки серед усіх випадків групи ЖГ відмічено, що за частотою перше рангове місце (46 випадків, 73,0 \%) належало помірному стеатозу печінки; друге - вираженому стеатозу (13 випадків, 
$20,6 \%)$; нарешті, у чотирьох випадках $(6,4 \%)$ відмічався слабковиражений стеатоз печінки.

За мікроскопічного дослідження матеріалу пункційної біопсії і зівставленні результатів біопсійного дослідження й гістологічного дослідження секційного матеріалу в 100 \% випадків встановлено ознаки стеатозу печінки. Однак у дев'яти випадках $(14,3$ \%) при дослідженні біопсійного матеріалу встановлено слабковиражений стеатоз печінки, хоча результати дослідження секційного матеріалу встановили наявність у даних випадках помірного стеатозу. У трьох випадках (4,8 \%) результати біопсійного дослідження вказали на наявність слабковираженого гепатозу, секційного матеріалу - свідчили про наявність стеатозу печінки 3 початковою перебудовою часточкової структури печінки.

У zpyni $\boldsymbol{X} \boldsymbol{\Gamma}$ вік пацієнтів склав 38,0 $(31,0 ; 52,5)$ років, коливаючись у межах 21-77 років; серед чоловіків - $34(32 ; 51)$ роки, серед жінок - $42(21 ; 77)$ роки $(\mathrm{p}=0,93)$. Частота ХГ істотно переважала серед чоловіків (дев'ять випадків, 75,0 \%) порівняно з жінками (три випадки, $25,0 \%), \varphi=2,57 ; p<0,01$. Відмінності груп пацієнтів 3 ХГ та ЖГ статистично вірогідні за віком, $38,0(31,0 ; 52,5)$ років проти $64,0(60,0 ; 73,0)$ років відповідно, $\mathrm{p}<0,01$, причому ця відмінність характерна виключно в чоловічому контингенті: 34,0 $(32,0 ; 51,0)$ роки проти $63,5(57,5 ; 71,5)$ років відповідно, $\mathrm{p}<0,01$.

У 7 (58,3 \%) випадках відмічений інфекційнний генез ХГ, у $4(33,3 \%)$ випадках - токсичний (алкогольний) і в 1 (8,3 \%) випадку - метаболічний.

Маса печінки склала $1890(1825 ; 1900)$ г, що $\epsilon$ більшим порівняно з $1876(1600 ; 1900)$ г у контрольній групі $(\mathrm{p}=0,03)$ і статистично не відрізняється порівняно з $1890(1868 ; 1900)$ г у групі пацієнтів із ЖГ $(\mathrm{p}=0,46)$. Макроскопічно капсула печінки була дифузно потовщена, білуватого чи білувато-сіруватого кольору; тканина печінки щільнувата, у деяких випадках в'яла, нижній край печінки заокруглений, на розрізі печінка в деяких випадках мала бурувато-коричневий, у деяких випадках - бурувато-жовтий колір.

Гістологічно у п'яти випадках $(41,7$ \%) мав місце хронічний активний гепатит, у чотирьох випадках $(33,3 \%)$ - хронічний персистувальний гепатит і в трьох випадках $(25,0 \%)$ - хронічний холестатичний гепатит. У частині випадків відмічалися мультилобулярні (зливні) некрози, тобто некрози деяких прилеглих печінкових часточок або мостоподібні некрози, які простягаються між двома сусідніми портальними трактами чи між портальними трактами і центральними венами. За хронічного активного гепатиту також відмічалися дистрофічні зміни (частіше за все гідропічна, аж до балонної, дистрофія).

Крім того, у тканині печінки відмічалися склеротичні зміни різного ступеня вираженості. Результати гістологічного дослідження встановили, що в п'яти випадках $(41,7$ \%) активність гепатиту була слабкою, у двох випадках (16,7 \%) помірною і в п'яти випадках $(41,7$ \%) - вираженою. Слабкий фіброз мав місце в шести випадках (50,0 \%), помірний - у п'яти випадках (41,7\%), тяжкий - в одному випадку $(8,3 \%)$.

Аналізуючи результати біопсійного дослідження печінки і зівставляючи їх з результатами дослідження секційного матеріалу, відмічено незбіг результатів у трьох випадках $(25,0 \%)$ за біопсійного дослідження, у двох випадках невірно визначено активність ХГ і в одному випадку ступінь вираженості фіброзу.

у групі ЦП вік становив 52,0 $(41,5 ; 65,5)$ роки (коливання $22-80$ років), серед чоловіків - 52 (39; 62) роки, серед жінок - 61 $(42 ; 69)$ рік $(\mathrm{p}=0,69)$.

328 спостережень у 15 (53,6 \%) випадках ЦП розвинувся в результаті токсичної дії алкоголю. Друге рангове місце серед причин розвитку ЦП прийшлося на хронічну патологію серцево-

Таблиця

Зіставлення величин специфічності та позитивної передбачувальної цінності ехографії та комп'ютерної томографії печінки за різних хронічних дифузних захворювань печінки

\begin{tabular}{|c|c|c|c|c|}
\hline Показники & Жировий гепатоз & Хронічний гепатит & Цироз печінки & Загалом \\
\hline \multicolumn{7}{|c|}{ Ультразвукове дослідження (n=105) } \\
\hline Специфічність & $54,6(20,0 ; 58,3)$ & $33,3(28,6 ; 40,0)^{*}$ & $70,0(40,0 ; 84,6)$ & $40,0(25,0 ; 70,0)$ \\
\hline ППЦ & $80,4(64,5 ; 91,1)$ & $70,0(50,0 ; 72,7)$ & $77,8(75,0 ; 86,4)$ & $75,0(50,0 ; 86,4)$ \\
\hline \multicolumn{7}{|c|}{ Комп’ютерна томографія (n=33) } \\
\hline Специфічність & $56,3(50,0 ; 78,8)$ & $58,4(50,0 ; 83,4)$ & $60,7(50,0 ; 85,7)$ & $56,3(50,0 ; 83,2)$ \\
\hline ППЦ & $85,4(65,7 ; 92,3)$ & $66,7(58,4 ; 83,4)$ & $76,4(57,5 ; 82,1)$ & $76,4(58,4 ; 88,0)$ \\
\hline \multicolumn{7}{|c|}{ Загалом УЗД і КТ (n=105) } \\
\hline Специфічність & $54,6(50,0 ; 62,5)$ & $50,0(33,3 ; 55,5)$ & $70,0(50,0 ; 84,6)$ & $50,0(40,0 ; 71,4)$ \\
\hline ППЦ & $81,3(64,5 ; 91,1)$ & $66,7(50,0 ; 72,7)$ & $77,8(75,0 ; 86,4)$ & $75,0(50,0 ; 86,4)$ \\
\hline
\end{tabular}

Примітка. ${ }^{*}$ - відмінність між методами діагностики вірогідна за $\mathrm{p}<0,05$ 
судинної системи (6 випадків, 21,4 \%), у виході якої формувався застійний, або мускатний, ЦП. У 5 (17,9 \%) випадках у пацієнтів з ЦП відмічено в анамнезі перенесений вірусний гепатит. У двох випадках $(7,1 \%)$ ЦП мав автоімунний генез. У 19 випадках $(67,9$ \%) дрібновузловий ЦП був основним захворюванням, а в дев'яти випадках $(32,1 \%)$ - супутньою патологією щодо хвороб серцево-судинної, респіраторної, травної систем. Щодо причини смерті, за ЦП значний відсоток випадків приходився на кровотечу з варикозно розширених вен стравоходу й шлунка (11 випадків, 39,3 \%), на печінково-клітинну, печінковониркову недостатність (8 випадків, 28,6 \%).

Виявлено тенденцію до зменшення маси печінки порівняно 3 групою контролю - 1500 $(1450 ; 1500)$ г проти $1876(1600 ; 1900)$ г відповідно, $\mathrm{p}=0,10$; статистично високо вірогідне зниження відносно групи пацієнтів із ЖГ - проти 1890 (1868; 1900) г, p<0,01 і групи пацієнтів із ХГ проти $1890(1825 ; 1900)$ г, $<<0,01$. Макроскопічно печінка щільної консистенції, дифузно деформована численними вузликами (розміром 0,3-0,5 см), на розрізі видно розділення тканини на округлі вузлики, обмежені фіброзними смугами і кільцями. Колір вузликів варіював: у частині випадків колір був блідо-коричневим, у частині - зеленувато-жовтуватим, а в решті - темно-червоним.

У всіх випадках за гістологічного дослідження фрагментів печінки відмічено порушення часточкової структури в результаті формування портального цирозу з потужними сполучнотканинними септами між хибними печінковими часточками. Портальні тракти значно розширені, зі склерозованою стромою і судинами. Гепатоцити хибних часточок місцями 3 осередковою, місцями 3 дифузною дрібно-, великокрапельною жировою дистрофією, однак траплялися поодинокі випадки, за яких ознаки жирової дистрофії гепатоцитів були відсутні. У частині полів зору визначалася гідропічна дистрофія гепатоцитів, а в частині полів - некротичні зміни клітин печінки. Траплялося збільшення кількості дрібних дуктальних елементів, що відбивало проліферацію в жовчних протоках. У поодиноких випадках відмічалися холестази. У частині полів зору в епітелії дрібних печінкових протоків визначалися дистрофічні зміни.

Серед усіх ЦП у даній групі переважав монолобулярний цироз печінки (коли вузлирегенерати будувалися на основі однієї подрібненої на фрагменти часточки) над мультилобулярним ЦП (коли до складу вузлів-регенератів входили фрагменти декількох часточок). Мономультилобулярний ЦП не траплявся.

При зіставленні результатів біопсійного дослідження печінки і гістологічного дослідження секційного матеріалу відмічено стовідсотковий збіг.

Подальшим кроком стала оцінка інформативності та діагностичної цінності УЗД й КТ щодо ХДЗП у зіставленні з результатами референтного секційного патоморфологічного дослідження. Узагальнена величина специфічності обох методів за ХДЗП становила $50(40 ; 71,4) \%$, позитивної передбачувальної цінності - 75,0 $(50,0 ; 86,4) \%$.

Центральні закономірності величин специфічності та позитивної передбачувальної цінності УЗД та КТ, за результатами порівняння із застосуванням критерію Манна-Уїтні, загалом, за винятком контингенту $3 \mathrm{XГ,} \epsilon$ зіставлюваними (табл. ), у той час як сонографічне дослідження $є$ більш інформативним за рахунок оцінки функціональних допплер-ехографічних показників кровообігу в портальній, гепатичній та лієнальній системах тощо.

\section{Висновки}

1. Застосовуваний у променевій діагностиці термін «хронічна дифузна патологія паренхіми печінки» $є$ збірним поняттям, що поєднує різні захворювання, які морфологічно проявляються переважно жировим гепатозом, хронічним гепатитом, цирозом печінки . Значна питома вага серед усіх хронічних дифузних захворювань печінки, припадає на жировий гепатоз (60,0%), в частині випадків на тлі хронічного венозного повнокров'я і цироз печінки різного генезу (26,7%).

2. Характерна тенденція до частішого розвитку жирового гепатозу, хронічного гепатиту, цирозу печінки у чоловіків. Медіана віку за жирового гепатозу - $64(60 ; 73)$ роки; за хронічного гепатиту $-38,0(31,0 ; 52,5)$ років, за цирозу печінки $52,0(41,5 ; 65,5)$ роки.

2. Центральні закономірності величин специфічності та позитивної передбачувальної цінності ультразвукової та комп'ютернотомографічної діагностики і комп'ютерної томографії є зіставлюваними. Узагальнена величина специфічності обох методів склала 50 $(40 ; 71,4) \%$, позитивної передбачувальної цінності - 75,0 (50,0; 86,4) \%; існує вірогідність $(1,9 \%)$ помилковопозитивної променевої діагностики хронічних дифузних захворювань печінки.

4. Результати комп'ютерної томографії істотно не відрізняються від ехографічних, проте, якщо комп'ютерна томографія супроводжується опроміненням і ризиком сенсибілізації до контрасту, за ним оцінюють щільність паренхіми, розміри, положення, контури й діаметри судин, то ультразвукове дослідження безпечне, дешевше, не потребує спеціальної підготовки і дозволяє оцінити як морфологічний, так і функціональний стан печінки, тобто більш інформативне.

5. Біопсія не $\epsilon$ стовідсотково точним методом діагностики хронічних дифузних захворювань печінки: незбіг результатів біопсійного і секційного досліджень за жирового гепатозу сягає $19,1 \%$, за хронічного гепатиту $-25,0 \%$.

Перспективи подальних досліджень - розробка алгоритмів застосування променевих методів діагностики хронічних дифузних захворювань печінки та оцінка їх прогностичного потенціалу. 


\section{Література}

1. Заболевания печени / И.В. Маев, А.Н. Казюлин, Ю.А. Кучерявый [и др.] // Рос. ж. гастроэнтерол., гепатол., колопроктол. - 2012. - № 3. - С. 49-56.

2. Комова А.Г. Принципы эффективной диагностики диффузных заболеваний печени на амбулаторном этапе / А.Г. Комова, М.В. Маевская, В.Т. Ивашкин // Рос. ж. гастроэнтерол., гепатол., колопроктол. 2014. - № 5. - C. 36-41.

3. УЗИ в диагностике цирроза печени / Д. Вычужанин, А. Черноусов, О. Афукова [и др.] // Врач. - 2011. № 6. - C. $82-85$.

4. Цыркунов В.М. Биопсия печени / В.М. Цыркунов, Н.В. Матиевская, Н.И. Прокопчик. - Гродно: ГрГМУ, 2013. $-56 \mathrm{c}$.

5. Carey E. Noninvasive tests for liver disease, fibrosis, and cirrhosis: Is liver biopsy obsolete? / E. Carey, W.D. Carey // Cleve Clin. J. Med. - 2010. - Vol. 77, № 8. - P. 519-527.

6. Gerstenmaier J.F. Ultrasound in chronic liver disease / J.F. Gerstenmaier, R.N. Gibson // Insights Imaging. 2014. - Vol. 5, № 4. - P. 441-455.
7. Hepatology 2015 / S. Mauss, T. Berg, J. Rockstroh [et al.]. Sydney: Flying Publisher, 2015. -655 p.

8. Mennone A. Needle-based confocal laser endomicroscopy to assess liver histology in vivo / A. Mennone, M. H. Nathanson // Gastrointest. Endosc. - 2011. - Vol. 73, № 2. - P. 338-344.

9. Practice of percutaneous needle autopsy; a descriptive study reporting experiences from Uganda / J.A. Cox, R.L. Lukande, S. Kalungi [et al.] // BMC Clin. Pathol. - 2014. - Vol. 14, № 1. P. 44.

10. Sebastiani G. How far is noninvasive assessment of liver fibrosis from replacing liver biopsy in hepatitis C? / G. Sebastiani, A. Alberti // J. Viral Hepat. - 2012. Vol. 19, Suppl. 1. - P. 18-32.

11. Trifan A. Checkmate to liver biopsy in chronic hepatitis C? / A. Trifan, C. Stanciu // World J. Gastroenterol. 2012. - Vol. 18, № 39. - P. 5514-5520.

12. Wang Y. Current strategies for quantitating fibrosis in liver biopsy / Y. Wang, J. L. Hou // Chin. Med. J. (Engl). - 2015. - Vol. 128, № 2. - P. 252-258.

\section{ПАТОМОРФОЛОГИЧЕСКАЯ ВЕРИФИКАЦИЯ УЛЬТРАСОНОГРАФИЧЕСКОЙ И КОМПЬЮТЕРНО-ТОМОГРАФИЧЕСКОЙ ДИАГНОСТИКИ ХРОНИЧЕСКОЙ ДИФФУЗНОЙ ПАТОЛОГИИ ПЕЧЕНИ}

\section{Ю.Я. Федуленкова}

Резюме. По результатам патоморфологического исследования 105 случаев (63 - жирового гепатоза (ЖГ), 12 хронического гепатита (ХГ), 28 - цирроза печени (ЦП), 2 - без патологии печени) оценена диагностическая ценность ультразвукового (УЗИ) и компьютерно-томографического (КТ) методов диагностики хронических диффузных заболеваний печени (ХДЗП). Показано, что диагностическая ценность УЗИ и КТ сопоставима. Обобщенная специфичность обоих методов составила $50(40 ; 71,4) \%$, позитивная прогностическая ценность - 75,0 $(50,0 ; 86,4) \%$. Информативность УЗИ выше за счет оценки как морфологических, так и функциональных показателей.

Ключевые слова: жировой гепатоз, хронический гепатит, цирроз печени, ультрасонография, компьютерная томография, патоморфология.

\section{PATHOMORPHOLOGICAL VERIFICATION OF ULTRASONOGRAPHY AND COMPUTED TOMOGRAPHY OF CHRONIC DIFFUSE LIVER PATHOLOGY}

\section{Yu.Ya. Fedulenkova}

Abstract. My morphological investigation of 105 cases (63 - fatty hepatosis (FH), 12 - chronic hepatitis $(\mathrm{CH}), 28-$ liver cirrhosis (LC), 2 - without liver pathology) the diagnosis value of ultrasound investigation (USI) and computed tomography (CT) methods of chronic diffuse liver pathology (CDLP) diagnosis was estimated. Diagnosis value of USI and CT is comparable. Generalized specificity of both methods was $50(40 ; 71,4) \%$, positive predicting value $-75,0(50,0 ; 86,4) \%$. Information value of USI is higher due to presentation of both morphological and functional parameters.

Key words: fatty hepatosis, chronic hepatitis, liver cirrhosis, ultrasonography, computed tomography, pathomorphology.

National Medical University (Kharkiv)

Рецензент - проф. І.С. Давиденко

Buk. Med. Herald. - 2015. - Vol. 19, № 3 (75). - P. 199-203

Надійшла до редакції 20.05.2015 року

(С Ю.Я. Федуленкова, 2015 